УДК 398.9(=161.1)(571.1.54)

DOI: $10.18101 / 2305-459 X-2020-2-34-38$

\title{
ПОСЛОВИЦЫ И ПОГОВОРКИ СТАРООБРЯДЦЕВ ЗАБАЙКАЛЬЯ
}

\author{
(C) Сафонова Людмила Викторовна \\ аспирант, \\ Бурятский государственный университет имени Доржи Банзарова \\ Россия, 670000, г. Улан-Удэ, ул. Ранжурова, 6 \\ safo_1984@mail.ru
}

\begin{abstract}
Аннотация. Пословицы и поговорки есть у каждого народа. Они отражают особенности уклада жизни, национального самосознания, исторической судьбы. Знание пословиц и поговорок дает возможность понять образ мыслей, характера народа. В современном обществе большое внимание уделяется актуальности и важности сохранения, собирания и изучения фольклора любого народа. Пословицы и поговорки старообрядцев Забайкалья мало изучены, поэтому представляют большой интерес для лингвистики. В настоящей статье раскрывается роль и место пословиц и поговорок в жизни старообрядцев, представлена тематическая классификация этих языковых единиц. Само разделение имеет условный характер, так как пословицы и поговорки характеризуются смысловой многозначностью и употребляются в прямом и переносном смыслах. Материалом послужили пословицы и поговорки, собранные учителями и учащимися образовательных учреждений МО «Бичурский район» в рамках конкурса «Языковое наследие старообрядцев Бичурского района».

Ключевые слова: пословица; поговорка; старообрядцы; воспитание; семья; труд; лень; слово; вера; родина.

\section{Для цитирования:}

Сафонова Л. В. Пословицы и поговорки старообрядцев Забайкалья // Вестник Бурятского государственного университета. Язык. Литература. Культура. 2020. Вып. 2. C. 34-38.
\end{abstract}

В фольклоре старообрядцев присутствуют многие жанры: заговоры, частушки, поговорки, пословицы, предания, лирические песни, похоронная причеть и т. д. В духовно-нравственной, семейной, социальной, культурной жизни современного старообрядческого села по-прежнему огромна роль пословиц и поговорок, поскольку они выступают в роли средства языковой идентичности семейских.

В каждой пословице или поговорке отражаются богатые трудовые традиции, многовековой опыт, праздники, обряды народа, которые связаны с земледельческим календарем, семейные обряды, присутствующие в жизни каждого старообрядца с рождения и до самой смерти. Все это дает возможность понять культуру, самобытность, ценности семейских. Благодаря многолетней истории пословицы и поговорки донесли до наших дней вековой опыт, мудрые советы наших предков, как достойно прожить эту жизнь.

В представлении народа пословицы и поговорки являются своеобразными кодексами морали. Это советы и наказы на все случаи жизни. В каждой пословице заложена пусть и маленькая, но нравственная идея. Пословицы - целый комплекс рекомендаций, которые выражают народное представление о человеке, о 
становлении личности, о нравственном, трудовом, умственном, физическом и эстетическом воспитании.

Образовательный и воспитательный потенциал пословиц и поговорок велик, на них учились и воспитывались разные поколения. Благодаря им постигаются основы воспитания староверов: ценностное отношение к матери, ценности семьи и семейных отношений, ценность труда на родной земле, ценность здорового образа жизни и т. д. Если использовать пословицы и поговорки в повседневной жизни, в образовательной деятельности, можно овладеть представлениями о таких качествах старообрядцев, как верность слову и делу, трудолюбие, порядочность, самоотверженность, терпимость, отзывчивость, сострадание.

Основы воспитания закладываются в семье. Старообрядцы считали, что семья - это основа жизни, система отношений между мужем и женой, родителями и детьми, между старшим поколением и младшим, основанная на крепком браке, глубоких и почитаемых родственных связях (Свой своему поневоле друг). Семьи были многодетные, и многодетность была нормой старообрядческой семьи (У семейских семейка на всю матерую скамейку; В дружной семье и чугунка больше, и щи слаще, и каша гуще). В пословицах ярко выражен родительский авторитет (Как Бог для людей, так и отеи с матерью для детей; Отиа с матерью почитать, так и горюшка не знать). Привязанность, любовь к детям отражаются в таких пословицах, как Тятенька и мамонька берегут дочь до венща, а муж жену до самого кониа, Для матери ребенок до ста лет дитенок. Тема выбора спутника жизни прослеживается в пословицах Девку надо в муке и в саже видеть, чтоб на ней жениться или Не заламывай рябину не вызревщи, не бери девку не вызнавщи. В то же время в пословицах и поговорках отмечаются и негативные стороны семейной жизни (Женился на скорую руку, да на долгую муку; Пьянииу приголубишь - свой век сгубишь; Лучше хлеб есть с водой, чем жить со злой женой). В пословицах нашли отражение и методы воспитания старообрядцев (Учи своих детей, да только без людей; Тятина рука высоко подымается да жалеючи прикладывается; Учи детей стыдом, а не кнутом).

В жизни каждого человека семья играет огромную роль. Человек счастлив, если у него есть надежный тыл - семья. Очень важно беречь семью, считаться с мнением других членов семьи, любить своих ближних. Семья с самого начала должна строиться на любви и уважении. Очень серьезно нужно подойти к выбору спутника жизни, если хочешь, чтобы семейная жизнь была долгой и крепкой.

Особо следует сказать о воспитательном значении пословиц в высмеивании негативных качеств. Высмеивались такие качества, как злость, лукавство, алчность (За доброе дело жди добра, за плохое - худа; В лихости и зависти нет ни проку, ни радости; У кого желчь во рту, тому все горько). Народная мудрость отучает от зависти и алчности, она учит умеренности и довольству (Широко шагаешь - мотню порвешь, с толком идешь - долго проживешь; Кто за все берется, тому ничего не дается).

У большинства народов трудовое воспитание является главной задачей, что нашло отражение в пословицах. Отличительная черта старообрядцев - особое трудолюбие, упорство, старательность, расчетливость. Старообрядцы резко осуждали лень и недобросовестное отношение к труду (Все должно быть трудово, а не трудово - худо и грех; Ленивым быть - век без ичигов ходить; Без 
дела жить, только небо коптить). К работе требовалось такое же серьезное и ревностное отношение, как к исполнению религиозных обрядов (Глубже пахать, больие хлеба видать).

Процесс труда у старообрядцев отмечался и украшался своеобразными традициями, выраженными в обрядах, празднествах, ритуалах (До Николь хоть ведро картошки да раскидай / Камни с неба лети, а огород до Николь посади). Все они отражали своеобразие культуры, быта семейских, но вместе с тем несли отпечаток особенных условий жизни староверов (Работать в поле успевай, только кичку поправляй; Языком ичиги не сошьешь, да и хлеб не напечешь). Так, у семейских существует свой годовой цикл праздников и обрядов, тесно связанный с земледельческим трудом (Лето работает на зиму, а зима - на лето; У мужика в августе три работь: и косить, и убирать, и сеять) [3].

Многочисленная группа пословиц и поговорок строится на противопоставлении таких понятий, как трудолюбие и лень (Kmo nоздно npocblnaemcя, mom кур не досчитается, а кто рано встает, для того петух поет; Человек от лени болеет, а от труда здоровеет; Трудягам пьшки, а лоботрясам иишки). Можно сказать, что старообрядцы резко осуждали тех, кто жил за счет других (Живи своим горбом, а не соседским добром; На чужой каравай рот не разевай, а пораньие вставай да свой наживай), ценили то, что заработано собственным трудом (Дорого то, что сам сробил).

Тем, кто работает спустя рукава, дают советы и настраивают на работу ( $\mathrm{Pa}$ ботай боле, и тебя помнить будут доле). Старообрядцы осознавали ценность труда и его необходимость для жизни (Кто любит трудиться, тому есть чем похвалиться; Тот человек иенный, кто смолоду работать привык), что от качества труда зависит результат, само по себе ничего не делается и, чтобы был результат, нужно приложить усилия (Не сади огородину наспех - вырастишь курам на смех; Потопал - холодец, поработал - леденец, пролежал на боку всему конец). Отношение к труду определяет положение и ценность человека в обществе. Поскольку подавляющее большинство людей трудится, постольку именно тот, кто способен заработать на жизнь своими силами, оказывается уважаемым членом общества (Чем трудней работа, тем выше честь).

В пословицах старообрядцев труд рассматривается как положительная деятельность, труд входит в круг практических ценностей старообрядца. Труд присутствует в нашей жизни постоянно. Это дает, понять, что работа никогда не закончится, она может сменяться, но не прекращаться. Труд не просто является постоянным спутником человека, он заполняет почти все время. Поэтому народ старается запечатлеть основные понятия труда в пословицах и поговорках.

Особое место среди устойчивых выражений занимают пословицы и поговорки о роли слова как мощного оружия в устах человека (Бритва больно скребет, но слово насмерть режет). Словом можно вылечить, а можно и убить. Поэтому за своими словами, своей речью надо следить, об этом и рассказывают пословицы и поговорки о слове.

Отличительной особенностью старообрядцев является умение держать слово. От того, как и каким языком выражается говорящий, умеет ли держать «язык за зубами», зависела репутация человека в общине (Лишнее слово досаду приносит; Кто держит рот на замке, у того душа здоровая). Вовремя сказанное слово 
могло как возвеличить человека, так и унизить его достоинство. Не нарушить взятое на себя обещание - дело чести, особенно для мужчин. Тем, кто любит поговорить без дела, старообрядцы сразу же прикрепляли соответствующие ярлычки (На одном краю чихнут, на другом - язык в лепешку разбивается). Пословицы учат ценить силу и значение доброго, искреннего и твердого слова [3].

У семейских существовал нравственный закон - ограждение себя и детей от плохого слова (В глаза не хвали, за глаза не кори; Гневу не пугайся, на ласку не кидайся). Верность слову противопоставлена обману (Кто правды не скажет, тот многих свяжет; Все минется, одна правда остается; Клевета что уголь: не обожжет, так замарает).

Пословицы охватили все стороны народной жизни, немало в них и суждений о религии, церкви и ее служителях. Староверы - это люди, отказавшиеся принять церковные реформы патриарха Никона и придерживающиеся церковных установлений Древней Руси. Они стараются сохранять все догматы, канонические положения, чины древнерусской церкви. Старообрядцы трепетно относились к вере отцов, стремились очистить церковь от чужого влияния, ревностно относились к разного рода изменениям, которые неизбежны при устройстве нового быта. Приверженность к старой вере в сочетании с новым заставляет подругому взглянуть на то, что не являлось ценностью в православии (Без бороды $u$ в рай не пустят; Человек ходит, а Бог, куда надо, туда его и водит; Не живи, как хочешь, аживи как надобно).

Пословицы и поговорки семейских большое внимание уделяют понятию «родина» как важной части жизни каждого человека (Своя земля и в горести мила; В Сибири 40 градусов - не мороз, сто верст - не расстояние). Понятие «родина» противопоставлено «чужбине» (Родима сторона - мать, чужая - мачеха; Земляка повидать - как в родном доме побывать). Пословицы призывают человека жить в том месте, где родился (С родной земли - умри, но не сходи) [3].

Таким образом, пословицы и поговорки, представляя наивную картину мира семейских, помогают понять духовные, нравственные ориентиры в их жизнедеятельности. Активно выполняя аккумулятивную функцию языка, они связывают духовно современных носителей говора с их предками, передают жизненный опыт старообрядцев, прививают любовь к их говору, повышают культуру речи, способствуют более глубокому изучению литературы.

Литература

1. Никонова Т. Н., Толстых Л. И., Куликова Н. АКоммуникативная культура старообрядцев Горного Алтая: монография. Горно-Алтайск: РИО ГАГУ, 2014. 104 с.

2. Семейские Забайкалья / под ред. Б. В. Базарова. Улан-Удэ, 2007. 200 с.

3. Словарь говоров старообрядцев (семейских) Забайкалья / под ред. Т. Б. Юмсуновой. Новосибирск: Изд-во СО РАН, Научно-издательский центр ОИГГМ, 1999.

4. Юмсунова Т. Б. Язык семейских - старообрядцев Забайкалья. М.: Языки славянской культуры, 2005. 288 с.

5. Даль В. Пословицы русского народа [Электронный ресурc]. URL: https://vdahl.ru (дата обращения: 30.05.2020).

6. Ефремова Т. Ф. Современный толковый словарь русского языка [Электронный pecypc]. URL: http://rus-yaz.niv.ru/doc/dictionary-efremova/index.htm (дата обращения: 25.06.2020). 
7. Леонов А. М. Возвращение к истокам: морально-этические традиции русских старообрядцев Забайкалья [Электронный ресурс]. URL: www.semeyskie.narod.ru (дата обращения: 27.06.2020).

8. Матвеева Р. П. Фольклорные традиции современного семейского села [Электронный ресурс]. URL: https://cyberleninka.ru/article/n/folklornaya-traditsiya-sovremennogosemeyskogo-sela/viewer (дата обращения: 24.06.2020).

9. Татаринцева М. П. Особенности бытования фольклора в среде старообрядцев [Электронный pecypc]. URL: https://сyberleninka.ru/article/n/osobennosti-bytovaniyafolklora-v-srede-staroobryadtsev/viewer (дата обращения: 20.06.2020).

\section{PROVERBS AND SAYINGS OF THE TRANSBAIKAL OLD BELIEVERS}

\section{Lyudmila V. Safonova}

Research Assistant of Russian Language and General Linguistics Department, Dorzhi Banzarov Buryat State University

6 Ranzhurova St., Ulan-Ude 670000, Russia

safo_1984@mail.ru

Abstract. Every nation has proverbs and sayings. They reflect the peculiarities of the way of life, national morale and historical destiny. Proverbs and sayings make it possible to understand the way of thinking, and character of the nation. In modern society much attention is paid to the relevance and importance of preserving, collecting and studying the folklore of any nation. Proverbs and sayings of the Transbaikal Old Believers have been little studied; therefore, they are of great interest for linguistics. The article reveals the role and place of proverbs and sayings in the life of Old Believers, presents a thematic classification of these linguistic units. The division of proverbs and sayings is conditional, since they are characterized by semantic polysemy and used in the literal and figurative senses. The material presented in the article was collected by teachers and students of educational institutions of Bichursky District within the competition "Linguistic Heritage of Old Believers of Bichursky District”.

Keywords: proverb; saying; Old Believers; education; family; work; laziness; word; belief; homeland. 